\title{
落葉層の蒸発特性に関する研究 \\ Experimental Study on the Characteristics of Evaporation \\ from the Layers of Fallen Leaves
}

林 誠二, 後藤光掌”, 須藤隆一”.

By Sei ji Hayashi, Goto Koki and Sudo Ryuichi

\begin{abstract}
The characteristics of evaporation from the layers of fallen leaves are studied in laboratory. To investigate the relationship among the rate of evaporation,the weather conditions and the moisture condition of layers, we use a wind tunnel. Temperature, humidity and wind speed are chosen for the index of weather condition, water content is chosen for the index of moisture condition in the layer.The result of this study shows that the rate of evaporation can be express as a function of the weather condition and moisture condition. The relationship obtained by the laboratory test is similar to the case of bare soil.

Keywords: fallen leaves, evaporation, wind speed,moisture condition,water content
\end{abstract}

1 .はじめに

森林土㙴での水及び物質移動機構を解明する試みは、水資源の確保や森林土壌の持つ自然浄化機能を理解 する上で屯、また酸性雨問題や地球温暖化といった大規模な長期間にわたる環境変動が、森林域に及ぼす影 響を予测する上であ非常に重要であると考えられる。森林土壤で水分や物質の移動を生じさせる主な要因は 降水であり、樹冠による遮断を免れて林内降雨（樹冠通過降雨+樹冠滴下降雨）や樹幹流として林床に達し、 樹種や季節により堆積形態は異なるが土壤表面を覆う落葉層を通過後、土壌へ浸透するというプロセスをた

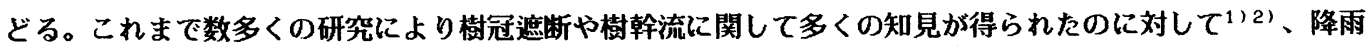
時における落莱層での水移動に関してあるいはその保水能力、蒸発特性といった降雨の遮断機能に関する研 究事例は、村井(1970)の保水能に関する研究等 3 ) があるものの数少なく、森林域での水収支において落葉層 の果たす役割やその重要性の有無に関して十分理解されていない点が多い。

そこで本研究では、落葉層の蒸発特性および落葉層による土壌からの蒸発抑制効果に着目し、その評価の 一環としてまず風洞を用いた室内実験により広葉樹の落葉層からの事発量を測定し、風速や堆積形態を変化 させる事でその蒸発特性を求めた。
学生員 東北大学大学院 工学研究科修士課程土木工学専攻
（テ980 仙台市青葉区荒巻字青葉）
** 正会員 工博 東北大学助教授 工学部土木工学科
(同上)
*** 正会員 理博 東北大学教授 工学部土木工学科
（同上） 


\section{2. 実験方法}

実験装置の概要を図-1に示す。風洞内の風速の鉛直 分布は風洞底部での㤂れが大きかったので、安定した 風速分布を得るためにカラム（内径 $32 \mathrm{~cm}$ ）を風洞内に $10 \mathrm{~cm}$ 突き出して設圆し、電子天秤でカラム総重量の経 時変化を自動計測し、その減少量から蒸発量を求めた。 同時に、風洞内の気温と湿度、および堆積した落葉の 葉面温度を T型熱電対を用い多チャンネルの自動記録 温度計により測定した。

\section{a) 気象条件}

設定風速は実際の森林域での観測デー夕を基 に、0,0.68,0.85,1.20,1.75(m/s) とし、気温 , 湿度と共にカラム上面より $20 \mathrm{~cm}$ の高さでの值 を用いた。また、日射は与えなかった。

b) 堆積条件

本実験には宮城県仙台市青葉山から9月中旬 に採取したコナラ（落葉広葉樹）の葉を用いた。 葉は時期的にみて土壌微生物による分解を受け 落葉直後に比べその表面はかなり軟化していた。 本実験を落葉層からの蒸発特性に、その堆積厚

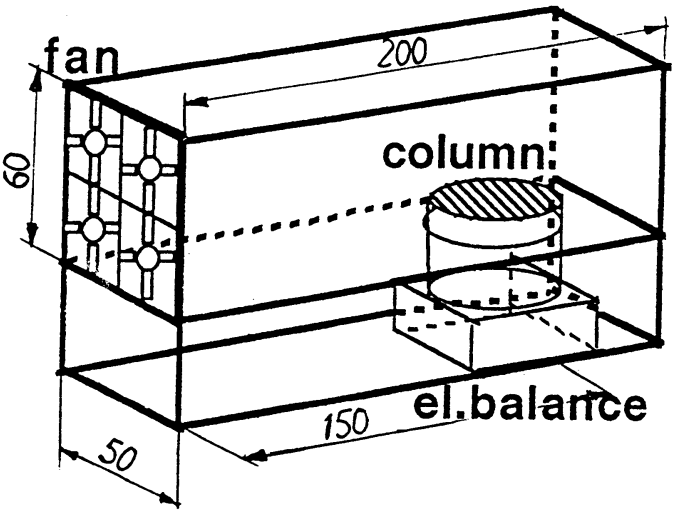

図一-1実験装置の概要

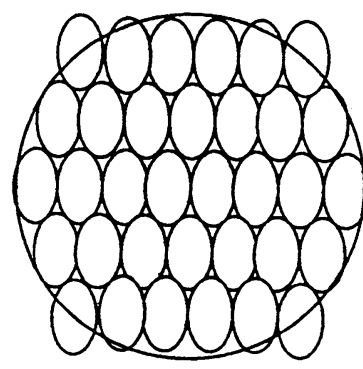

(a)

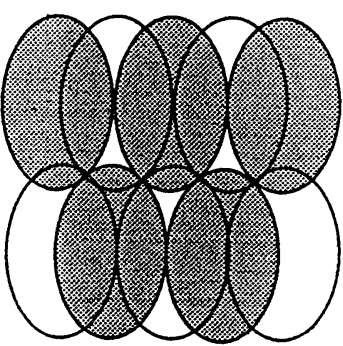

(b)
図-2 堆積形態 と平面的な堆積分布が及ぼす影響の評㑯という点で行う事から、非常にランダムに堆積した実際の森林土壤 表面の落葉層を直接切り出して用いる事はせず、ほぼ同形の葉を断熱を施したカラム底部に規則的な分布を 与え、乾燥後、葉がカラムから飛び出さないため落葉層表面とカラム上面の距離が3cmとなるよう堆積させた。 平面分布は図-2(a)に示すように、葉を互いに重ねずに同一方向に出来るだけ密に並べる形態をとりこれを1 層とした。堆積厚は上記の平面分布を図-2(b)に示すように重ね、現場観測を基に1,2,3,5層を設定した。尚、 落葉層が充分な湿洞状態で実験を開始する為に、採取した葉は24時間以上含浸させた後、所定の方法で保持 し得ない水分を落下させたものを用いた。

\section{3. 結果及び考察}

\section{3-1. 蒸発速度に及ぼす堆積厚と風速の影響}

堆積厚や風速が落葉層からの蒸発に対して及ぼす影響 を把握するため、堆積厚や風速をパラメーターとして各 実験毎の蒸発速度の経時変化を求めた。その一例として 図-3は一定風速 $(1.75 \mathrm{~m} / \mathrm{s})$ での各堆樍厚毎の、図-4は堆 積厚が3層で各実験每に風速を変化させた場合の蒸発速度 の経時変化を示した。両図に見られるように、堆積厚が 1層の場合を除き葉の重なりを持った落葉層からの蒸発は

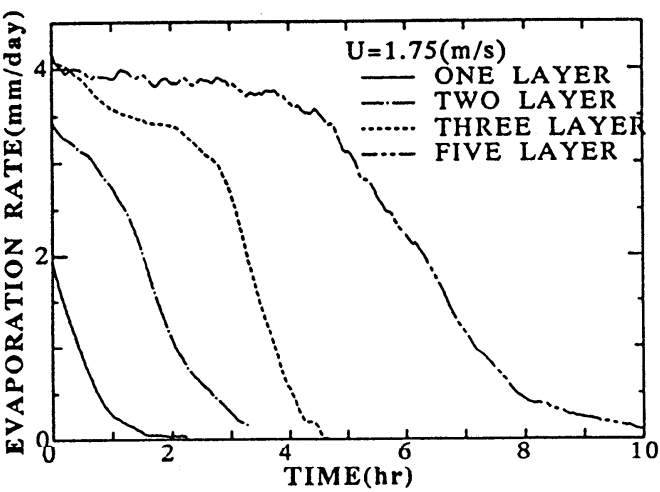

园一－3 蒸発速度の経時変化 いずれむ、表面が十分湿洞している実験開始時から蒸発速度が一定かもしくは、緩やかに減少していく恒率 的な弥発期間を有し、その後、急激に蒸発速度が減少するという傾向を示した。堆積厚との関係は、1 5層 
と厚さが増すにつれ恒率的な蒸発期間が長くなるという 結果が得られた。これは堆積厚が増すと葉の重なり合う 部分が増加し、より多くの水分が層内に保持されるため と考えられる。また、風速の増加に伴い実験初期の最大 蒸発速度は增大するがその一方で、恒率的な蒸発期間は 短くなりその後の蒸発速度の低下屯より急激となるとい った傾向が実験全般を通してみられた。

3-2. 含水比による蒸発速度の変化

a) 含水比

上記の結果から落葉層からの蒸発に層内に保持される 水分量が大きく影響すると考えられ、両者の関係を把握 するためまず落葉層の水分状態を表す指標として、堆積 した葉の全乾重童に対する含有水量の比を含水比Wとし て定義した。各実駼每に実験前に固場容水量状態にある 落葉属の全重量と、実験終了後力ラムより取り出し $2 \sim 3$ 時間乾燥 $\left(40^{\circ} \mathrm{C}\right)$ 後、求め大葉の乾重量加落葉層の团場 容水量状態の含水比（初期含水比）を、また実験中の力 ラム重量の減少量を用い蒸発過程での落葉層の含水比を 各々求めた。図-5は各堆積厚毎の初期含水比の平均值を 示したものである。上述したように堆積厚が増すにつれ 含水比は增加しており、葉の重なる枚数が増すほど水分 の保持量が增加する事が分かる。

b）含水比による蒸発速度の変化

落葉層の水分状態が蒸発に及ぼす影嫴を理解するため、 上記の含水比Wを用い蒸発速度との関係を求めた。図-6 は同一の堆馩厚で各実験毎に風速を変化させた時の、図 -7は同一の風速で各実駼毎に堆積厚を変化させた時の各 々、含水比Wに対する蒸発速度の変化を示したものであ る。含水比が8〜3の範囲では各ケースとも層内に充分に 水分を保持しているため、図-7の3層と5層の場合に示さ れる様に蒸発量は堆積厚の違いから生じる含有水分量の 差よりも各実駼毎にほぼ一定に設定した大気侧の気象条 件の影響を受けると思われ、その蒸発速度の変化も緩や かである。一方、含水比が2前後まで低下すると含水比の 減少に伴い蒸発速度は急激に減少し、気象条件よりも落 葉層の水分状態が蒸発に大きく影響する事が推测される。 そこで、この様な特性を示す落葉層からの蒸発過程で の層内の水分鉛直分布を求める事により、定義した層全 体の含水比Wとの関係から層内に保持された水分の蒸発 に対する寄与形態を把握することを試みた。上記の実験 と同じ堆積形態を持つ4つのカラム（内径 $18 \mathrm{~cm}$ ) を一定

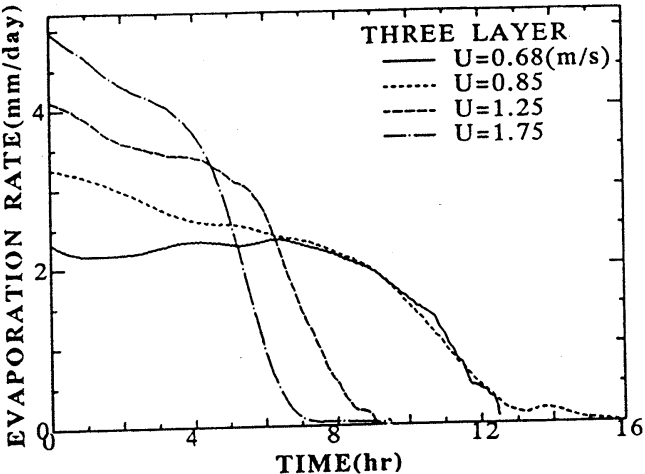

図-4 蒸発速度の経時変化

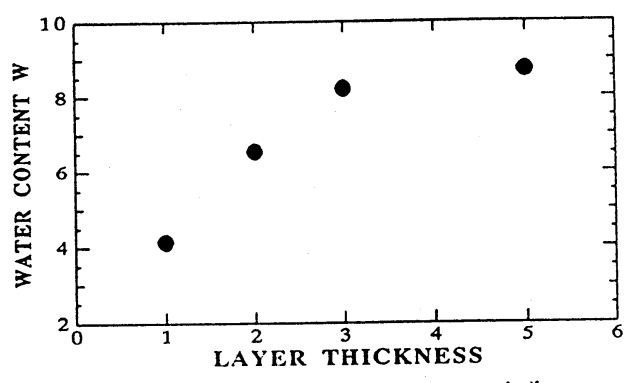

图一 5 層厚による含水比の変化

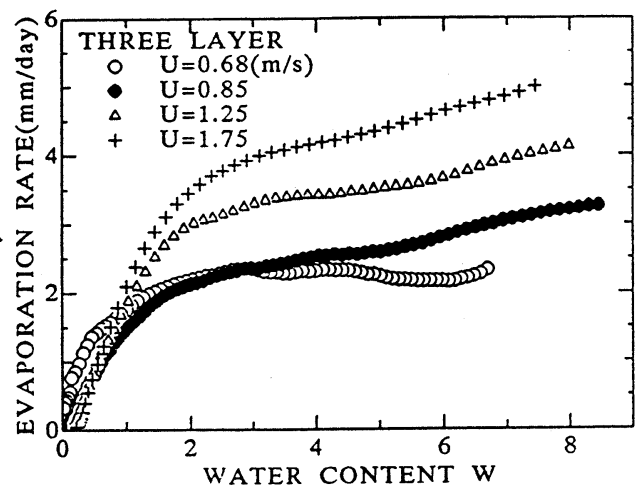

图-6 含水比による蒸発速度の変化

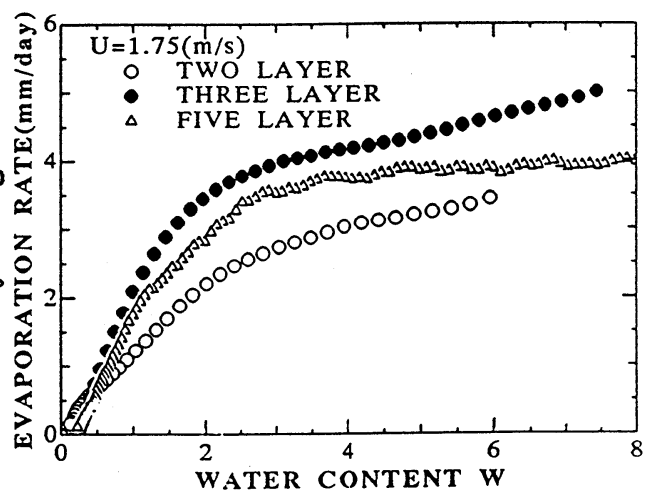

目一 7 含水比による蒸発速度の変化 
風速与えた風洞内に2列に設置し、一定時間每に重量を 測定しその減少量から各々含水比が7〜6、5 4、3〜2、1 を目安に一つずつカラムを取り出し、葉の形態や各層 毎の水分状態を観察すると共に、層全体の含水比と各 層毎別々の含水比を求めた（この時力ラムを風向に沿 って並べるため、移流等の影響により厳密には4力ラム とも同一条件下にあるといえないが、測定した各力ラ ムの重量減少量（蒸発速度）はほぼ等しかった事から、 ここでは同一条件下にあるとみなして扱った）。図-8 には堆樍厚が3層、風速は $0.85 \mathrm{~m} / \mathrm{s} の$ 時の結果を示した。 実験開始と共に直接大気と接触する表属部分は葉自体

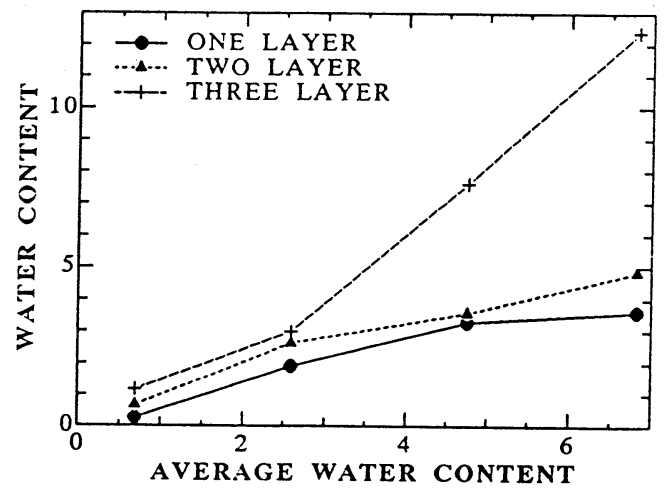

図-8 蒸発過程での含水比の鉛直方向の恋化 は含水しているが、開始時に葉面に付着していた水滴は速やかに蔒発する事が確認された。実駼結果から層 全体の含水比が3以上であれば効率的な蒸発が生じていると考えられるが、図に示したように全体の含水比が 6〜7にあっても表層の葉の含水比は既に3程度に減少しており2層目の含水比も全体に比べ小さい值となって いる。一方で、点発が進行し全体の含水比が3付近まで減少するにつれ、底層の含水比が急激に減少したのに 対し、表層部の葉は含水比が僅かに減少するだけで含水比3前後の水分状態を維持している。また、含水比2 .6の時点で表層の葉に乾燥収縮が見られず、2層目と3層目の間だけでなく1層と2層の間にも水分が保持され ていた事が確認された。以上より、恒率的な蒝発期間では気象条件から決定する大気側の苲発能力に応じて 表層の湿潤した葉表面から蒸発が生じ、その時、表層部の水分の減少から生じる圧力勾配により層間に保持 された水分は、液体の水として鉛直上方向へ図-8にみられるように蒸発により生じた鉛直方向の水分量の差 をある程度小さくするまで移動を生じ続けると考えられる。一方、時間の経過と共に大気侧の蒸発能力に対 し鉛直上方への移動量が下回るにつれ表層の葉は乾懆が進み、層全体の含水比は2を下回り蒸発速度は急激な 低下をみせる。この時蒸発は、僅加落葉層底部に保持された水分の水蒸気拡散を主体とする蒸発への移行 が生じていると考えられる。この样に充分湿潤状態にある落葉層からの蒸発特性は、層内の水分状態の变化 からみて裸地表面からの場合4) と類似しており、個々の葉は土柆子に比べ非常に大きく、平面的形状物体の 堆積構造であるにも関わらずこの样な特性を有しているのは、主に微生物による分解を受け表面が軟化した 葉の高い浸水性および透水性のためであると推測される。

\section{4. 結論}

今回行ったいくつかの実駼から、落葉層からの蒸発量は層内の水分状態に依存しており、蒸発機構は裸地 表面の場合と類似している事が明かとなった。また層内の水分状態を表す指標として含水比Wを用いること で、気象データと含水比の測定值から、ある程度落葉層からの蒸発量が算定し得ることが示され、モデル化 への大きな足撕りになったと思われる。

\section{参考文献}

1)例えば、近藤純正・渡辺力・中園信・石井正典：森林における降雨の遮断蒸発のモデル計算, 日本気象学 会誌"天気", Vol.39.N0.3,p.51 59, 1992

2)例えば、端野道夫・吉田弘・中谷達志：実森林樹幹流データによる降雨遮断モデルの比較検討，水工学論 文集, Vol.35, p.87 92, 1991

3)村井宏：森林植生による降水の遮断機能についての研究，林試研究報告第232号，p.54〜60, 1970

4)中野政詩：土の物質移動学, 東京大学出版会, p.107〜117, 1991 